\title{
Adam Exists in the Mind of Man: The Existential Phenomenological Ontology of Human Predicament
}

\author{
Maduabuchi Dukor \\ Department of Philosophy, Nnamdi Azikiwe University, Awka, Nigeria \\ Email: madudukor@yahoo.com
}

Received 25 February 2015; accepted 3 March 2015; published 4 March 2015

Copyright (C) 2015 by author and Scientific Research Publishing Inc.

This work is licensed under the Creative Commons Attribution International License (CC BY). http://creativecommons.org/licenses/by/4.0/

c) (i) Open Access

\begin{abstract}
The road map from Abrahamic order is phenomenologically a trajectory to a world of disorder. Order and disorder in the age of globalization is not hanging on a vacuum but is deeply embedded and historically structured in the creation story which Biblical and Quranic literatures are the main original sources, which the sciences complemented in a most profound theoretical and observational global context though philosophically and phenomenologically empty. The sin and disobedience of the ancient and early Christian and Islamic accounts explain the current human misery and insecurity as episodes or consequences of unnatural actions; a punishment from the unseen hand whose mercy is not reducible to any known planet-earth ruler, but to human nature, intuition and wisdom not found in science and technology.
\end{abstract}

\section{Keywords}

God, Adam, Mind, Phenomenology, Ontology, Existentialism, Religion, Science, Atheism and Insecurity

\section{Introduction}

It seems that there is a phenomenological road map from the Abrahamic tradition to the present crisis-ridden world order which can be called Adamic plague or crisis. To distillate a new order of justice fundamental enough for the renewal of ethical life in a globalize world, we should appreciate the Adam in our existence, its phenomenology and the consequent pathology of sin and disobedience.

The road map from Abrahamic order is phenomenologically a trajectory to a world of disorder. Again the essence of this phenomenon seems to be sin and disobedience and its consequences. The problem of mankind as a 
result of sin and disobedience is deeply embedded and historically structured in the creation story which Biblical and Quranic literatures are the main original sources, but which the sciences complemented in a most profound theoretical and observational global context though philosophically and phenomenologically empty. The question of order and disorder in the era of globalization is, therefore, inherently a composite question of the phenomenology of existence in a scientific world and pathology of sin and disobedience arising from the post Abrahamic world disorder.

Phenomenology, as the study of appearance, essence and being, is brought here to engage ancient, modern and contemporary problems that have confronted mankind, all reducible to sin and disobedience or the biblical refrain in Hosea (4:6): "my people are destroyed for lack of knowledge". The Bible, hence, underscores the epistemological problem of human predicament which had been his preoccupation of ancient Greek pre-Socrates philosophers, for instance, Heraclitus in form of interrogations on appearance and reality and substance and form. This is the problem which the contemporary philosophers of phenomenology has strenuously and rigorously engaged from appearance or the ugly human experiences into the level of sustained and penetrating ontology, metaphysics and epistemology. Therefore the phenomenological and existential concern of the paper is how far lack of knowledge led to human self-destruction has and what knowledge or epistemological gap need to be bridged to sustain humanity on this planet earth.

Hence there are five theoretical lights to this inquiry, or rather phenomenological paradoxes of ontological and existential significance that cannot be sentimentally ignored in the search for security and civilization in the world. One, theological predictions are pari-pasu with scientific predictions in the present world order. Two, the complementarities of science and religion in the life wire of individuals is giving way for atheistic existentialism. Three, atheistic existentialism has inexorably led to secularism and the survival of the fittest. Four, survival of the fittest, the apron spring of Charles Darwin's philosophy, has created different levels of disorder which science cannot comprehend. Therefore, five, philosophy and culture demand a phenomenological inquiry into the existence and the origin of order and disorder in a globalized, scientific and technological world. Philosophy and culture qua science and religion in a world of order and disorder therefore are best mediated by a phenomenological inquiry.

\section{Sin, Disobedience and Human Predicament}

It is pertinent to extray the theoretical stance of the Biblical and Quranic postulations on sin and disobedience as the background of order and disorder in any era, as much as in globalization in an interface of science and religion. God said, let us make man in our image, after our likeness: and let them have dominion over the fish of the sea, and over the fowl of the air, and over the cattle, and over all the earth, and over every creeping thing that creeps upon the earth (Gen, 1:26). Hence, and the Lord God formed man out of the ground and "breathed into his nostril the breath of life, and man became a living soul” (Gen, 2:7). And the Lord God commanded the man, saying. "Of every tree of the garden thou mayest freely eat ... but of the tree of the knowledge of good and evil, thou shall not eat of it: for in the day that thou eatest thereof thou shall die" (Gen, 2:16-17). And He Lord God "caused a deep sleep to fall upon Adam, and he slept, and he took one of his ribs and closed up the flesh instead thereof... and the rib, which the Lord God had taken from man, made into a woman, and brought her into the man (Gen, 21-22).

Now the "serpent was more subtle than any beast of the field which the Lord God had made ..." (Gen, 3:1). But of the fruit of the tree which is in the midst of the garden, God had said, "ye shall not eat of it, neither ye touch it, lest ye die" (Gen, 3:3). And the serpent said unto the woman, "ye shall not surely die ... for God do know that in the day ye eat thereof, then your eyes shall be opened, and ye shall be as gods, knowing good and evil" (Gen, 3:4-5). And when "the woman saw that the tree was good for food and that it was pleasant to the eyes, and a tree to be desired to make one wise, she took of the fruit thereof, and did eat and gave also unto her husband with her, and they knew that they were naked; and they sewed fig leaves together, and made themselves aprons" (Gen, 3:6-7).

And the Lord God said unto the serpent, because thou has done this, thou are cursed above all cattle, and above every beast of the field ... unto the woman he said, I will greatly multiply the sorrow and they conception .... and unto Adam he said, because thou has hearkened unto the voice of thy wife, and has eaten of the tree, of the tree, of which 1 commanded thee, saying thou shall not eat of it, cursed is the ground for thy sake; in sorrow shall thou eat of it all the days of thy life ...” (Gen, 3:14-17). 
The Holy Quran and the Bible have similarities and parallels on the issues concerning Adam and Eve, sin and disobedience as well as their consequences for mankind. They agree that Adam and Eve were forbidden to take fruit in the Garden of Eden. But according to Islam, Adam and Eve did not intentionally transgress the law. They were seduced by Satan. Holy Quran says; "but Satan caused them both to sleep" (Quran, 2:37). Similarly in the Bible Eve said that the Serpent (Satan) beguiled her and she did eat. Whether this is an error in judgment or mistake, the consequences for mankind have been very grave. The Quran says they begged Allah for forgiveness thus: our Lord we have wronged ourselves and if thou forgive us not and have not mercy on us, we shall surely be of the losers (Quran, 7:24, part 8, p. 142). And Allah accepted their forgiveness. And verily, we made covenant with Adam before and but he forget sand we found in him no disobey us (Quran, 20:116, part 16, p. 307). World religions including Bhuldka, Hindu etc generally agree that whosoever commits a sin, commits it only against his own soul and whosoever does right, it is for the benefit of his own soul; and whosoever does evil, the burden thereof will be on it.

This background of man painted by the Bible and Quran, to say the least, in the absence of alternative revealed source, can be said to have castrated the fate and progress of mankind.

Therefore, there are two anthropological and ontological critical factors arising from the Holy books, which aggressively point their fingers from behind on man and hence for shadows man's destiny in phenomenological and pathological dimensions. These are disobedience and sin. The two phenomena are asymmetrical; sin is disobedience and disobedience is sin. These two historical and providential phenomena of human nature have influenced human destiny; culturally, socially, economically and politically in individual, collective, group, societal, and national existence.

Sin and disobedience have not only created phenomenological and existential quagmires and pathologies in individual predicates and group affairs in the world but has also influenced human history so negatively for it to be called providential divine destiny, as aspect of philosophy of history or Hegelian philosophy of history. One direct ancestory of this original sin is the psychological pathologies afflicting humanity in terms homosexual practices, lesbianism, pedophiles, garontophiles and so on. If man is disordered as it were, the society will be equally or more affected. For Sunny Isu, "such disordered persons need our prayers and counselling. We should only hate their sins and detest their unnatural behaviours but not their persons because Christ can change them" (Isu, 2013). The phenomenological pathology (or curse on man) has created the need for its studies in humanities and social sciences, ethics, law, science and law. Hence there seems to be an ontological connection between that man is cursed or has the imprimatur of sin on his forehead and the evolving multiplicity of human problems in all field of human endeavor. In other words it seems that human problems, contradictions, crisis etc are anthropologically sowed by act of commission or commission in the primitive human mind. This thinking yields what can be called human predicament, yet the theologians call it theodicy; philosophers call it "phenomenology", and political scientist call it "politics". Accordingly theodicy, problems, and politics have permeated other areas of human interests like science, society and law underpinning them positively or negatively.

In theodicy scholars appreciates the impact of evil on man in form of natural and manmade disasters. The tension between the problem of evil and man often negate the proof of the existence of God, thereby leaving the fate of the world in the hand of man. The phenomenology of sin and disobedience originating from "Adam's exist in man's mind", a subjective origin for that matter, is the reason why man is today being harassed by both his subjective burdens of sin and disobedience and his objective environment. Hence it seems that moral and physical evils are predicted on phenomenological pathology of sin. Is this casual phenomenology reversible?

\section{The Elusive Truth}

Philosophers appreciate the problems of man and set out professionally to dig into life without any iota of pretence that things could be otherwise. It commissions itself to discover the reality which from the time of Socrates has remained elusive, and to properly engaged itself with all face of human problems through logic, epistemology, metaphysics and ethics. Since Edmund Husserl a new vistas of knowledge has been developed to tackle problem, evils and human crises associated with human history and experience. This is what is called phenomenology, a philosophical method of acquiring truth within the realm of human experience different from idealism and rationalism.

Social scientists, political scientists, sociologists, anthropologists and historians have since the dawn of ages been concerned with human problems and will not finish their business in near future. This is because political, sociological, historical and anthropological problems would continue to multiply with population of humans. 
Since all social scientific approaches to the study of man are based on experience, and the religious approaches are predicated on the divine. Phenomenology as applied here mediates them as a rigorous science, to investigate the ontology and phenomena of sin and disobedience as displayed and found in experience. Thinkers and scholars in all fields should, therefore, be concerned over the deteriorating nature of human social, economic, political and cultural problems since the creation episode, spanning through the ancient, the Middle Ages, the renaissance, the modern and the postmodern.

The period between the middle ages and the modern saw a heightened search for reality and the interrogative interface between religion and science, yet the problem of man persist giving room for an alternative phenomenological inquiry.

\section{Atheism and Adamic Existence}

In this enquiry, the role of philosophy will be appreciated by a snap at the history of philosophy as the history of search for truth, reminiscent of the ancient Greek and African period. The scholastic (middle age). The renaissance, the modern and the contemporary periods are all various responses to different phases of human problem. A critical look at this philosophical trajectory will show that atheism swiftly becomes structured in human mind because of the onslaught of science on religion and because of man's frantic desire to escape from dread and anguish. That is why existentialism stood out from modern philosophy as a contemporary antidote to wild life created by the enlightenment period. Yet their it's philosophy did not solve the problem of mankind as notable among them, Kierkegaard, Jaspers, Heidegger, Nietzsche, Sartre, Marcel etc.; propounded that a existence precedes essence as they go along and do not live out a predetermined essence or blueprint (Lacey, 1976). Existentialism by its over investment on the freedom of man not only re-invented Charles Darwin survival of the fittest and atheism but also multiplied wildest choices and crisis of humanity bereft of moral fibre. Although Darwin's origin of species is disconnected from the Biblical or Quaranic account his theory of natural selection abides poignantly on human destruction because of lack of knowledge. The world wars I and II, ideological pluralism, racism, colonialism, reo-colonialism, religious fundamentalism, sectarianism, economic and political upheavals, terrorism, immorality and to sum them all, the failure of human wisdom generated another phase of inquiry into the predicament of man. One, is the formation of United Nations with its human rights and transnational values, after the Second World War and two is the post-modernist philosophers (post modernism) following the interrogations of the enlightenment Europe by Marxist and Frank Fort Schools led by Karl Marx and Herbarmas respectively. Since then, the world has known no peace politically, economically and religiously. There are Adamic political and economic crisis much as there are Adamic Ebola, Adamic enterovirus D68, Adamic broken health system much as there are Adamic overall insecurity of life, all associated with Globalization. Hence we have in the encyclopaedia of troubles of mankind, the Adamic Globalization.

\section{World Insecurity and Globalization}

Insecurity in the world is keeping a date with history of social anomie, an internal disorder capable of truncating or transforming the world. This is a "state of nature", "state of irrationality" symbolized in the conflicts within and among nations and the insecurity picture depicted in Newspaper such as Bank robbery, murder, gunman, shooting, attack, killings, kidnapping, poisoning, corruption, ethnic conflicts, religious conflict, political instability educational crisis environmental degradation and so on. The "state" is responsible for taming and containing these ills with the instrument of a responsible ombudsman, sovereign or leviathan using "man's second nature, a character-based notion of intellectual virtue and security" (Dukor, 2013). The other notion of security is reliabilism, "an ethical virtue which is an aspect of first nature" (Dukor, 2013), capacities or faculties that man is born with that reliably produces true security. The extent to which some state governments appreciate the current state of insecurity much less than the super powers is simply dangerous even though the developed countries are also part of canvas of the vicious circle of insecurity engulfing the globe. However, the current global security challenges falsify conventional security theories in the history and practice of multiethnic democracy and nationhood. As global phenomenon insecurity is phenomenological and is an Africa problem; it is historical and political. All in all security question is a phenomenological matter because of the relationship between the first nature security virtue and the second nature, instrumentalist, responsibility security virtue which has collapsed since modern politics and governance. Hence it is important also to pointedly reflect on the implications and actualizations of the classical, modern, contemporary and postmodern theories of statehood, power and go- 
vernance as the past are crystal enough no matter their ideological predilections. Plato's theory of the state guarantees the security of every individual in their appropriate strata given their callings in the society. Aristotle's theory of the state guarantees the security of even the slaves (Aristotle, 1963). St. Augustine's theodicy and city of god in the medieval time reserve evil for insecurity and good for insecurity in his divine political solutions to natural and metaphysical evils (Augustine St., 1963). George Hegel representing modernity postulated "I" and "other" and by implication "good" and "evil" in the evolutionary ladder of humanity which in post modernist culture has been criticized by Karl Marx and the Frankfurt school's critical theory of Germany (Calhoun, 1997). Jurgen Habermmmas, Theodor Adorno, Herbert Marcus and Max Horhermer are in the Vanguard of this post modern revolution that challenged Hegel and his predecessor John lock who argued that it is labor that imparts value on land but also Adam Smith who argues, that the wealth of nations are predicted on market forces of demand and supply, competition and profit maximization, all of who have wittingly or wittingly produced the modern insecurity crisis in the world where thoughts are baked in the oven of Western imperialism (Smith, 1985).

The state of insecurity in the world at large, save that the advanced countries employed effectively the instrumental second nature response which, at any rate works on the alter of discipline and rule of law, is an embedded flux in the boat of modernization and westernization as absolutes in social change. Westernization and modernization promoted science and corruption beyond the security of life and its current phase and globalization, promoted conflict of values that many nations now do not know where to place their humanity. While some have argued that the world has become flat as a result of globalization in the information age fostering economic growth, other argue that globalization is spiky and mountainous exposing regions to heightened competition and not flat (Feioke, Moon, \& Park, 2008). In both senses there are truths but there is a falsehood in not tracking the existential value of human security entailed in globalization of all cultures and values. In a non racist and non scientific sense globalization is flat but not spiky and does not foster competitiveness and economic growth at the expense of the other in the postmodern spirit of the Frankfort school of thought. Yet Globalization is lopsided because it is still naked modernization and westernization which is mountainous like Afghanistan and Pakistan in social insecurity and Nigerian in social freedom and state of insecurity today.

The external dynamics of globalization in internationalizing crimes and insecurity are still the upfront crisis of modernity. This truncation instead of transformation of the world is like a wild fire from soft-power diplomacy, a cultural alienation on rampage, without explicit hard power adventurism that characterized the coercive diplomacy and pax Americana of the days of Nixon to George Bush. Globalization in the naked sense of modernization and westernization has therefore from its optimum performance as an agent, of Satan or God done very well in 1) synchronization an differentiation of domestic politics and international relations; 2) complex interdependent networking; 3) world value change through soft power of cultural imperialism and; 4) hard power value change hidden under the cloak of soft power which has naked powers in forms of insecurity and crimes exported to other parts of the world where governance is a problem, and rule of law non-existence: (Dukor, 2012) where Greed and corruption accompanying modernity crisis have devalued the place of conscience and good governance in human security and generated skepticism against rule of law, the military and the police in maintaining peace and order in the society in the negative transformation of the world by the imperial global bandwagon.

\section{Sustainable Future of Theistic Humanity}

It is imperative therefore, to stress here that the motive and end of governments, associations, societies, nations, nation states and leadership is security and good life. It is not surprising to see this in all forms of governments, even in bad governments and this Ipso-facto is the attribute of communism, authoritarianism, socialism, liberal democracy etc. yet as each of this forms of government transform in obedience to social change insecurity increases. Security challenges since Plato, Aristotle, St. Augustine, Thomas Hobbies, J.J. Rousseau, John Locke and Modern Democratic theories have exposed the limits of idealism and empiricism in security theorizing. Hence the first nature security virtue, reliabilism and the second nature security virtue, responsibilism and instrumentalism, idealist and empiricist approaches respectively, are today challenged separately and collectively by the globalization and networking of insecurity in the world. This is because there seems to exist on the planet-earth an evolutionary impasse in the face of pervading injustices, immorality, and irresponsibility. Humanity is in need of deconstruction using the best philosophical ideals from the classical traditions of either the Greeks 
or the ancient Africa philosophy. Global security, prosperity and progress is predicated on wisdom, reason, justice and morality and will in turn yield global citizenship, global responsibility and global leadership for educated integrated and corrupt-free earth population. The security challenges in the modern world is a salient nature's clarions call to listen to the mother-earth, the planet-earth or the unadulterated human conscience on the need for man to phenomenologically retrace his journey from sin and disobedience to the right course of honesty, truth and sincerity in free-will and actions. It is therefore imperative that the first nature of man virtue of reliabilism instead of the second nature virtue of instrumentalism is the evolutionary, phenomenological and corrupt-free rhythm ad pro-active motif for the reconstruction and deconstruction of human virtue of honesty, truth and sincerity in governance.

The sin and disobedience of the ancient and early Christian and Islamic account explains the current human misery and insecurity as episodes or consequences of unnatural actions; a punishment from the unseen hand whose mercy is not reducible to any known planet-earth ruler, but to human nature, intuition and wisdom not found in science and technology and in theistic humanism of Africa philosophy (Dukor, 2013). Theistic Humanism is a philosophical principle or doctrine designating African ideas of man, universe and God. Hence the ideas of Theism and Humanism are jointly and inseparably applicable to African culture. Theistic Humanism is based on the belief that Theism and Humanism are both compatible and harmonious elements of black metaphysical and epistemological world-view (Dukor, 2001).

\section{Conclusion}

The objective of this thesis is to pointedly delineate the root of evils in the world in the Adamic sin and disobedience, to postulate that every scourge, plague and sin all or large scale political or economic failure in the world is Adamic and then try to re-draw the road map for solutions to human predicament from phenomenological existential reflections in the sustainable future of Theistic Humanism. This is to be guided by one, my people are destroyed by lack of knowledge (Hosea, 4:6) two, unexamined life is not worth living (Socrates) and three, man know thyself (Egyptian proverb).

\section{References}

“Aristotle” (1963). In L. Strauss, \& J. Cropsey (Eds.), History of Political Philosophy (2nd ed., pp. 74-77). London: University of Chicago Press.

Smith, A. (1985). An Inquiry into the Reasons and Causes of the Wealth of Nations. Modern Library, College Editions USA, Chapter II.

Calhoun, C. (1997). Introduction. In C. Calhoun (Ed.), Habermas and Pubic Sphere (pp. 1-48). Cambridge, MA: MIT Press.

Feioke, R., Moon, M. J., \& Park, H. J. (2008). Is the World flat or Spiky? Rethinking Governance, Implication of Globalization for Economic Development. Public Administration Review, 68, 24-35.

Lacey, A. R. (1976). A Dictionary of Philosophy (p. 158). London: Routledge and Kegan Paul.

Dukor, M. (2001). Theistic Humanism-African Philosophical Tradition. Journal of Indian Council of Philosophical Research, XVIII, 64

Dukor, M. (2012). State of Insecurity and Globalization. The Guardian Wednesday August 22 and Thursday August 22, p. 52.

Augustine, St. (1963). In L. Strauss, \& J. Cropsey (Eds.). History of Political Philosophy (2nd ed., pp. 151-166). London: University of Chicago Press.

Isu, S. (2013). The Pope's Comment on Homosexually. In the Guardian, Sunday, October 6, p. 54

The Holy Bible (1997). Tennesse, USA, Holy Bible Publishers, Gen. 2 and 3.

The Holy Quoran (1997). UK, Islamic International Publication Ltd., 2:37, 7:24, 20:116. 